Journal of The Magnetics Society of Japan Vol. 13, Supplement, No. S1 (1989) (C) 1989 by The Magnetics Society of Japan

\title{
EFFECT OF INTRODUCED GASES ON MAGNETIC PROPERTIES OF VACUUM DEPOSITED CO-Cr FILMS
}

Kiyokazu TOHMA, Tatsuaki ISHIDA, Kazuyoshi HONDA, Yasuhiro KAWAWAKE, Taro NAMBU and Ryuji SUGITA

Central Research Laboratories, Matsushita Electric Ind. Co., Ltd. 3-15, Yagumo-nakamachi, Moriguchi, Osaka 570, JAPAN

ABSTRACT Investigated is the effect of $\mathrm{Ar}, \mathrm{N}_{2}, \mathrm{O}_{2}, \mathrm{CH}_{4}$ and $\mathrm{H}_{2} \mathrm{O}$ on magnetic properties of $\mathrm{Co}-\mathrm{Cr}$ films prepared with a web-coater type evaporating system. In introducing any of these gases, $\mathrm{H}_{\text {keff }}$ decreases with inereasing gas flow rate. With the introduction of $\mathrm{O}_{2}$ or $\mathrm{H}_{2} \mathrm{O}$, $\mathrm{H}_{\mathfrak{C}}$ decreases and $\mathrm{M}_{\mathbf{S}}$ increases, while the introduction of the other gases, $\mathrm{H}_{\mathrm{C}}$ and $\mathrm{M}_{\mathbf{S}}$ are almost constant. In the vaeuum deposition of $\mathrm{Co}-\mathrm{Cr}$ films, $\mathrm{N}_{2}$ and $\mathrm{CH}_{4}$ are as inert as $\mathrm{Ar}$ is, and they scatter evaporating $\mathrm{Co}$ and $\mathrm{Cr}$ atoms. $\mathrm{O}_{2}$ is active enough to react selectively with $\mathrm{Cr}$, and deteriorates the magnetic properties. $\mathrm{H}_{2} \mathrm{O}$ decomposes to oxygen and hydrogen during the deposition.

\section{INTRODUCTION}

Co-Cr films are prepared mainly by means of sputtering and vacuum deposition, in which atmosphere is one of the most influential factors on magnetic properties of the films.

Various effect of impurity gases on magnetic properties and microstructure of Co-Cr films have been reported [1]-[4].

However, the effect of gases on $\mathrm{Co}-\mathrm{Cr}$ films prepared at high deposition rate has not been studied, though these films are most promising from the industrial point of view.

In this paper, an experimental study is reported on the effect of introduced gases on magnetic properties of $\mathrm{Co}-\mathrm{Cr}$ films which are deposited directly on polymer substrates at high rate with continuous vacuum deposition.

\section{EXPERIMENTAL}

As shown in Fig. 1, the polymer substrates transported around a cylindrical can were treated with ion beam, following which $\mathrm{Co}-\mathrm{Cr}$ films were deposited on the treated substrates. The substrates used were polyimide films of $10 \mu \mathrm{m}$ in thickness.
The diameter of the can was $40 \mathrm{~cm}$. The ion beam was generated with a Kaufman type ion source, the grid diameter of which was 8 $\mathrm{cm}$. The ion source ionized Ar introduced at flow rate of $20 \mathrm{cc} / \mathrm{min}$. The $\mathrm{Co}-\mathrm{Cr}$ films deposited on the substrates treated with the ion beam have the reproduced voltage as high as that of the Co-Cr films with a

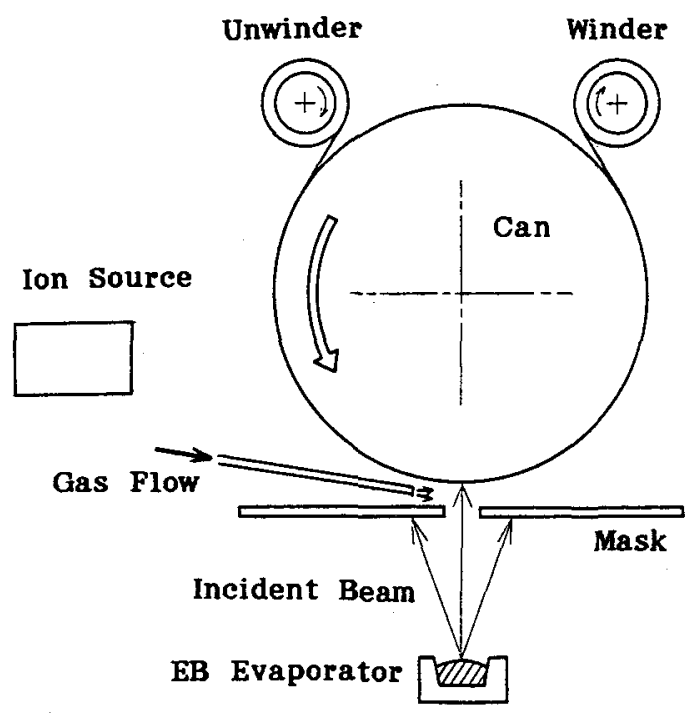

Fig. 1 Schematic illustration of the web-coater type evaporating system. 
Ti underlayer [5]. The evaporation source was a 270 degrees deflection type electron beam evaporator.

Gases, except for $\mathrm{H}_{2} \mathrm{O}$, were introduced near the mask (Fig. 1), and the gas flow rate was controlled with gas flow meters. The total pressure and the partial pressure of the gas were measured with an ionization vacuum gauge and a quadrupole mass filter, respectively. Introduced gases were $\mathrm{Ar}, \mathrm{N}_{2}$, $\mathrm{O}_{2}$ and $\mathrm{CH}_{4}$. Before the deposition, the substrates were degassed thoroughly, since polymer substrates had contained $\mathrm{H}_{2} \mathrm{O}$ [6], [7]. The degassing was done by transporting the substrates around the heated can in the vacuum chamber.

$\mathrm{H}_{2} \mathrm{O}$ was not introduced from the outside of the chamber. The partial pressure of $\mathrm{H}_{2} \mathrm{O}$ during the deposition was varied by changing the can temperature during the degassing of the substrates. Because the residual $\mathrm{H}_{2} \mathrm{O}$ in the substrates was discharged by contact of the substrates with the heated can just before the deposition.

Hysteresis loops were measured with a vibrating sample magnetometer (VSM). Perpendicular anisotropy field, $H_{k e f f}$, was estimated from the in-plane hysteresis loop. Orientation of c-axis, $\Delta \Theta_{50}$, was estimated from an $\mathrm{X}$-ray rocking curve of hep (002).

\section{RESULTS AND DISCUSSION}

\section{Effect of Gases}

Conditions of the degassing and the deposition are shown in Table 1 . When Ar was introduced at the rate of $0.51 / \mathrm{min}$, the increase of pressure in the chamber was $3 \times 10^{-5}$ Torr.

Fig. 2 shows the gas flow rate dependence of perpendicular coercive force, $\mathrm{H}_{\mathrm{c}(\mathrm{v})}$, in-plane coercive force, $\mathrm{H}_{\mathrm{c}(\mathrm{i})}$, anisotropy field, $\mathrm{H}_{\mathrm{keff}}$, and orientation of c-axis, $\Delta \theta_{50}$. With increasing Ar, $\mathrm{N}_{2}$ or $\mathrm{CH}_{4}, \mathrm{H}_{\mathrm{c}(\mathrm{i})}$ and $\Delta \Theta_{50}$ increased, $\mathrm{H}_{\mathrm{k} e \mathrm{ff}}$ decreased and $\mathrm{H}_{\mathrm{c}}(\mathrm{v})$ was nearly constant. On the other hand, with the introduction of
$\mathrm{O}_{2}, \mathrm{H}_{\mathrm{c}(\mathrm{v})}, \mathrm{H}_{\mathrm{c}(\mathrm{i})}$ and $\mathrm{H}_{\mathrm{keff}}$ decreased and $\Delta \Theta_{50}$ increased.

Saturation magnetization, $M_{S}$, of the Co-Cr films increased by about $100 \mathrm{emu} / \mathrm{cc}$ with introducing $\mathrm{O}_{2}$ at the rate of 0.5 $1 / \mathrm{min}$, while the introduction of the other gases did not change the value of $M_{S}$ which was about $450 \mathrm{emu} / \mathrm{cc}$.

Fig. 3 shows the scanning electron microscope (SEM) views of the surface and the cross-section of the Co-Cr films. The films shown in (a) and (b) were prepared with the introduction of $\mathrm{N}_{2}$ and $\mathrm{O}_{2}$ at the rate of $0.5 \mathrm{l} / \mathrm{min}$, respectively. The surface shown in (a) was rougher than that shown in (b). In comparison with the crosssection shown in (b), that shown in (a) had a clearer columnar strueture.

Fig. 4 shows the spectra of $X-r a y$ photoelectron spectroscopy (XPS) on $\operatorname{Cr}\left(2_{\mathrm{p} 1 / 2}\right), \operatorname{Cr}(2 \mathrm{p} 3 / 2)$ and $\operatorname{Co}(2 \mathrm{p} 3 / 2)$ in the Co-Cr films. These analyses were performed at $0.04 \mathrm{um}$ in depth from the surface of the films. For the film (a) prepared with $\mathrm{N}_{2}$, $\mathrm{Co}$ and $\mathrm{Cr}$ had the same profiles as those of the reference film (c) prepared without the introduction of gases. It was supposed that there was no nitride in the vacuum deposited Co-Cr films. For the film (b) prepared with $\mathrm{O}_{2}, \mathrm{Cr}$ was combined with $\mathrm{O}_{2}$, but no peak of Co-oxide could be observed. In this experiment, $\mathrm{Ar}, \mathrm{N}_{2}$ and $\mathrm{CH}_{4}$ had the same tendency of the effect on the magnetic properties of the vacuum deposited Co-Cr films. $\mathrm{N}_{2}$ and $\mathrm{CH}_{4}$ were as inert as

Table 1 Conditions of the degassing and the deposition in the experiment on the effect of gases.

\begin{tabular}{|c|c|c|}
\hline \multirow{3}{*}{ Degassing } & Can Temperature & $320{ }^{\circ} \mathrm{C}$ \\
\hline & $\begin{array}{l}\text { Contact Time } \\
\text { (Sub. and Can) }\end{array}$ & 5 sec \\
\hline & Bressure gf & 20 mTorr \\
\hline \multirow{4}{*}{ Deposition } & Can Temperature & $250^{\circ} \mathrm{C}$ \\
\hline & Deposition Rate & $0.4 \mu \mathrm{m} / \mathrm{sec}$ \\
\hline & Thickness & $0.3 \mu \mathrm{m}$ \\
\hline & $\begin{array}{l}\text { Pressure of } \\
\text { Background }\end{array}$ & $5 \times 10^{-6}$ Torr \\
\hline
\end{tabular}



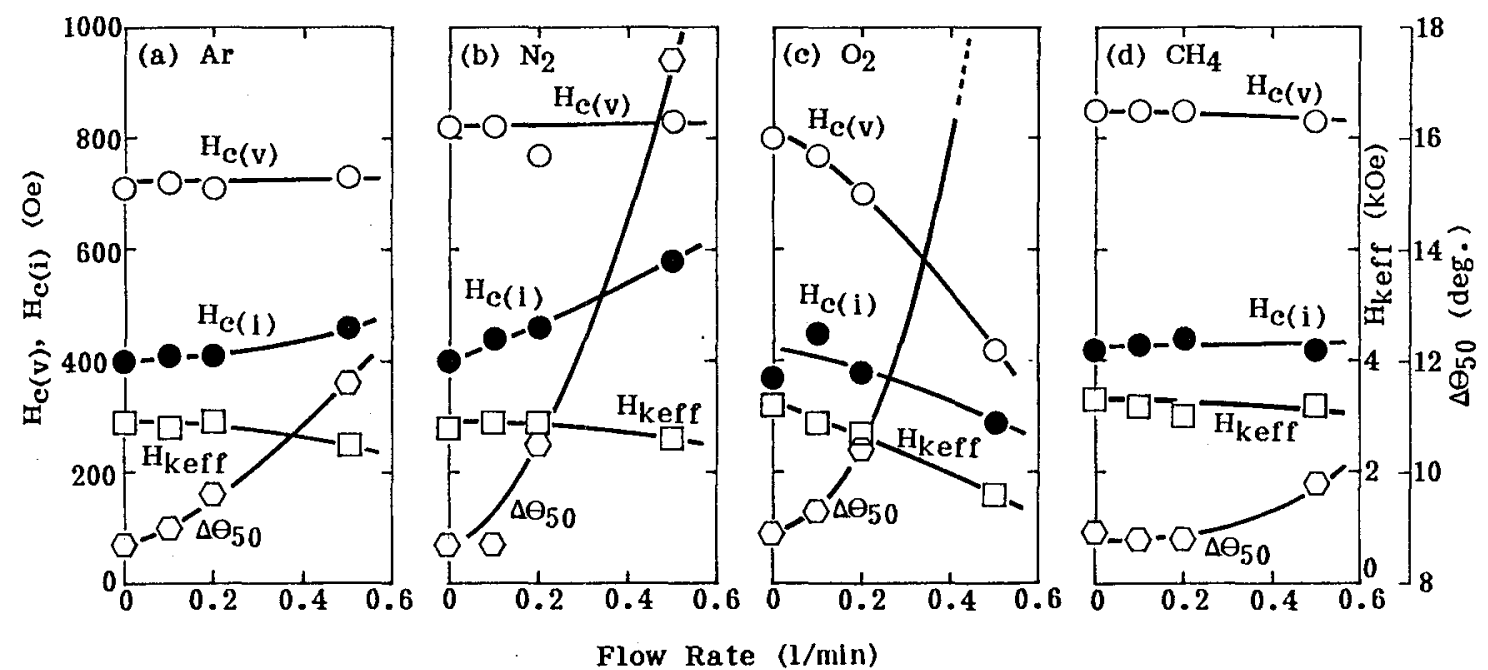

Fig. 2 The gas flow rate dependence of $\mathrm{H}_{\mathrm{c}(\mathrm{v})}, \mathrm{H}_{\mathrm{C}}(\mathrm{i}), \mathrm{H}_{\mathrm{keff}}$ and $\Delta \Theta_{50}$ of the Co-Cr films prepared with the introduction of $\mathrm{Ar}$ (a), $\mathrm{N}_{2}$ (b), $\mathrm{O}_{2}$ (c) and $\mathrm{CH}_{4}$ (d).

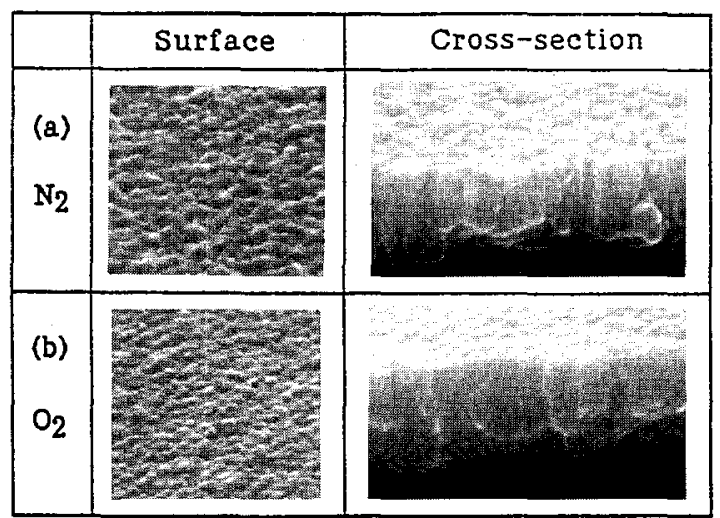

$0.3 \mu \mathrm{m}$

Fig. 3 SEM views of the surface and the cross-section of the $\mathrm{Co}-\mathrm{Cr}$ films prepared with the introduction of $\mathrm{N}_{2}$ (a) and $\mathrm{O}_{2}$ (b).

Ar. These gases only scattered evaporating $\mathrm{Co}$ and $\mathrm{Cr}$ atoms. The scatter disordered the orientation of c-axis, resulting in the decrease of $\mathrm{H}_{\text {keff }}$ and the increase of $\mathrm{H}_{\mathrm{C}(\mathrm{i})}$. And the scatter made the columnar structure clearer because of the self shadowing effect.

$\mathrm{O}_{2}$ had different effect from Ar, $\mathrm{N}_{2}$

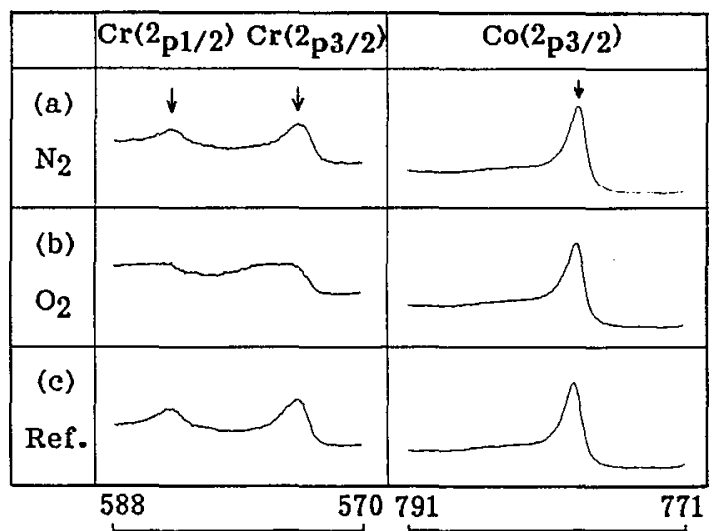

Binding Energy (eV)

Fig. 4 The XPS spectra of $\mathrm{Cr}$ and $\mathrm{Co}$ in the Co-Cr films prepared with the introduction of $\mathrm{N}_{2}$ (a), $\mathrm{O}_{2}$ (b) and reference (c).

and $\mathrm{CH}_{4} \cdot \mathrm{O}_{2}$ combined selectively with $\mathrm{Cr}$, which caused of the decrease of $\mathrm{H}_{c}$ and the increase of $\mathrm{M}_{\mathrm{S}}$. It had been supposed that $\mathrm{Cr}$ weakened the intercolumnar magnetic coupling by the segregation of $\mathrm{Cr}$ near the grain boundaries and $\mathrm{Cr}$ reduced $\mathrm{M}_{\mathrm{S}}$ of $\mathrm{Co}-\mathrm{Cr}$ alloy by filling $3 d$ energy band of Co with electrons of Cr. Oxidation of $\mathrm{Cr}$ was 
considered to take from these functions of Cr mentioned above, resulting in the decrease of $H_{c}$ and the increase of $M_{S}$.

\section{Effect of Water}

The polymer substrates contained various gases. Table 2 shows a composition

Table 2 Composition in pressure of discharged gases during the degassing.

\begin{tabular}{|l|c|c|c|c|c|}
\hline $\mathrm{Gas}$ & $\mathrm{H}_{2}$ & $\mathrm{H}_{2} \mathrm{O}$ & $\mathrm{N}_{2}$ & $\mathrm{O} 2$ & $\mathrm{CO}_{2}$ \\
\hline $\mathrm{P}_{\mathrm{P}} / \mathrm{P}_{\mathrm{t}}$ & 0.02 & 0.94 & 0.02 & $<0.01$ & $<0.01$ \\
\hline
\end{tabular}

Table 3 Conditions of the degassing and the deposition in the experiment on the effect of water.

\begin{tabular}{|c|c|c|}
\hline \multirow{3}{*}{ Degass ing } & Can Temperature & $25-320^{\circ} \mathrm{C}$ \\
\hline & Contact Time $)$ & $5 \mathrm{sec}$ \\
\hline & $\begin{array}{l}\text { Pressure of } \\
\text { Background }\end{array}$ & 20 mTor r \\
\hline \multirow{4}{*}{ Deposition } & Can Temperature & $250^{\circ} \mathrm{C}$ \\
\hline & Deposition Rate & $0.4 \mu \mathrm{m} / \mathrm{sec}$ \\
\hline & Thickness & $0.25 \mu \mathrm{m}$ \\
\hline & $\begin{array}{l}\text { Pressure of } \\
\text { Background }\end{array}$ & $5 \times 10^{-6}$ Tor $\mathrm{r}$ \\
\hline
\end{tabular}

in pressure of discharged gases during the degassing. In Table 2, $P_{p}$ and $P_{t}$ are partial pressure of each gas and total pressure of gases discharged, respectively. $\mathrm{H}_{2} \mathrm{O}$ was the most part of content among gases discharged during the degassing. The partial pressure of $\mathrm{H}_{2} \mathrm{O}$ during the deposition was varied by changing the can temperature during the degassing of the substrates. Table 3 shows the conditions of the degassing and the deposition.

Fig. 5 shows the content of $\mathrm{H}_{2} \mathrm{O}$ and $\mathrm{H}_{2}$ in the vacuum chamber when the substrates ran which were degassed at various can temperature. $I\left(\mathrm{H}_{2} \mathrm{O}\right)$ and $I\left(\mathrm{H}_{2}\right)$ are the ion currents of $\mathrm{H}_{2} \mathrm{O}$ and $\mathrm{H}_{2}$, respectively. The ion currents were measured with the quadrupole mass filter. Degassing temperature is the can temperature during the degassing. In Fig. 5 (a), the substrates ran around the can in the same conditions as those of the deposition except that the electron beam for evaporator was off. The lower degassing temperature, the more $\mathrm{H}_{2} \mathrm{O}$ discharged during the deposition. In this case, $\mathrm{O}_{2}$ was $1.0-$ $1.3 \times 10^{-8} \mathrm{~A}$ constantly at all range of the

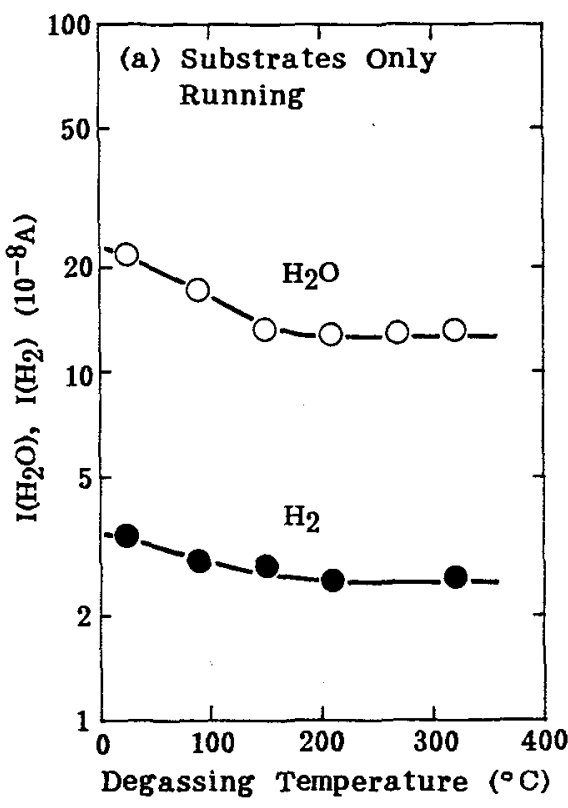

Fig. 5 The degassing temperature dependence of $\mathrm{H}_{2} \mathrm{O}$ and $\mathrm{H}_{2}$ content in the course of running the substrates without the deposition (a) and during the deposition (b). 
degassing temperature. Fig. 5 (b) shows the content of $\mathrm{H}_{2} \mathrm{O}$ and $\mathrm{H}_{2}$ during the deposition. $\mathrm{H}_{2} \mathrm{O}$ decreased to $10^{-8} \mathrm{~A}$ from $10^{-7} \mathrm{~A}$, on the other hand $\mathrm{H}_{2}$ increased to $10^{-7}$ A from $10^{-8}$ A. $\mathrm{H}_{2} \mathrm{O}$ increased considerably, as the degassing temperature was below about $200^{\circ} \mathrm{C}$. The ion currents of $\mathrm{O}_{2}$ was less than $10^{-10}$ A through the range of the degassing temperature.

Fig. 6 shows the degassing temperature dependence of $H_{c(v)}, H_{c(i)}, H_{k e f f}$ and $\Delta \theta_{50}$ of the Co-Cr films. The magnetic properties and the orientation of c-axis were constant when the degassing temperature was above $200^{\circ} \mathrm{C}$. Below $200^{\circ} \mathrm{C}$, with the degassing temperature lowering, $\mathrm{H}_{\mathrm{c}}(\mathrm{v}), \mathrm{H}_{\mathrm{c}}(\mathrm{i})$ and $H_{k e f f}$ decreased, and $\Delta \theta_{50}$ increased. These changes of the properties corresponded to the increase of the content of $\mathrm{H}_{2} \mathrm{O}$ discharged.

The effect of $\mathrm{H}_{2} \mathrm{O}$ on the magnetic properties of the $\mathrm{Co}-\mathrm{Cr}$ films was much the same as that of $\mathrm{O}_{2}$. It was obvious that $\mathrm{H}_{2} \mathrm{O}$ decomposed to hydrogen and oxygen during the deposition, because $\mathrm{H}_{2}$ increased to about ten times and $\mathrm{H}_{2} \mathrm{O}$ decreased to about a tenth part. $\mathrm{O}_{2}$ decreased during the deposition, because $\mathrm{O}_{2}$ combined selec-

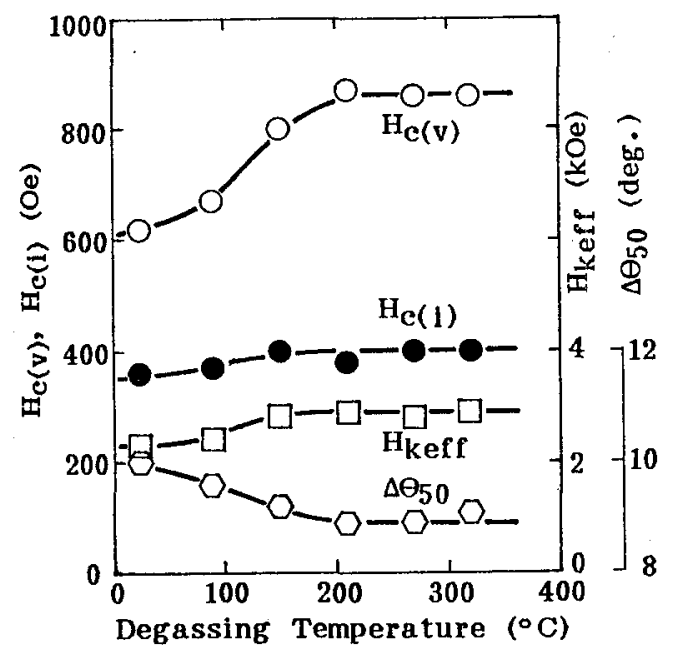

Fig. 6 The degassing temperature dependence of $H_{c(v)}, H_{e(i)}, H_{k e f f}$ and $\Delta \Theta_{50}$. tively with $\mathrm{Cr}$. $\mathrm{M}_{\mathrm{S}}$ of the Co-Cr films increased by about $30 \mathrm{emu} / \mathrm{cc}$, as the degassing temperature was from $200^{\circ} \mathrm{C}$ down to $25^{\circ} \mathrm{C}$.

The cause of the decomposition of $\mathrm{H}_{2} \mathrm{O}$ was inferred as follows. $\mathrm{H}_{2} \mathrm{O}$ molecules collided with the electrons from the electron gun for the evaporator or evaporating $\mathrm{Co}$ and $\mathrm{Cr}$ atoms. Oxygen atoms combined with evaporating $\mathrm{Cr}$, and were deposited together with other evaporating atoms on the substrates.

\section{SUMMARY}

Investigated was the effect of gases on the magnetic properties of the $\mathrm{Co}-\mathrm{Cr}$ films deposited at high rate directly on the polymer substrates with the continuous vacuum deposition. The results were following.

$\mathrm{N}_{2}$ and $\mathrm{CH}_{4}$ were as inert as $\mathrm{Ar}$, and such inert gases only scattered the evaporating atoms. The scatter did not only disorder the orientation of $\mathrm{C}$-axis, but also made the columnar structure clearer because of the self shadowing effect.

$\mathrm{O}_{2}$ was combined selectively with $\mathrm{Cr}$, and the oxidation took from the functions of $\mathrm{Cr}$ in the $\mathrm{Co}-\mathrm{Cr}$ films.

$\mathrm{H}_{2} \mathrm{O}$ had much the same effect as $\mathrm{O}_{2}$, since $\mathrm{H}_{2} \mathrm{O}$ decomposed to oxygen and hydrogen during the deposition.

\section{ACKNOWLEDGMENTS}

The authors would like to thank Messrs. N. Kaminaka and $Y$. Sakamoto of Matsushita Electric Industrial Co., Ltd. for their guidance. They also would like to thank Mr. Y. Murakami and Misses S. Inazato and $Y$. Nakamura of Matsushita Technoresearch, Inc. for their assistance.

\section{REFERENCES}

[1] T. M. Coughlin, E. R. Wuori and J. H. Judy: J. Vac. Sci. Technol., Vol.20, No.2, p.171, 1982. 
[2] J. A. Thompson and D. A. Stevenson: IEEE Trans. Magn., MAG-21, No.5, p.1441, 1985.

[3] S. Iwasaki, K. Ouchi, M. Kimura and K. Saiki: J. Mag. Soc. Japan, Vol.10, No.2, p.61, 1986.

[4] M. Futamoto, Y. Honda, S. Saito and K. Yoshida: Extended Abstracts of The 47th Autumn Meeting; The Japan Society of Applied Physies and Related Societies, 27p-ZK-7, p.397, 1986.

[5] R. Sugita, K. Tohma, K. Honda, Y. Kawawake, N. Echigo and Y. Murakami: Intermag'89, KA-09, 1988.

[6] I. Sumita, A. Kouchiyama, R. Washino, Y. Nakayama and M. Asanuma: J. Mag. Soc. Japan, Vol.11, No.2, p.69, 1987.

[7] S. Iwasaki, K. Ouchi and K. Saiki: Digests of 9 th Annual Conference on Magnetics in Japan; The Magnetics Society of Japan, 26aA-8, p.8, 1985. 